\title{
ASTIN MEMOIRS
}

\section{By PaUl Johansen}

Nous avons pensé que les assurances contre l'incendie pouvaient aussi s'étayer du calcul. (T. J. Barrois, 1835)

To a mathematician 25 is a very uninteresting number: Just the square of a small prime. For a historian it means an epoch. If 25 years bring us back to one of the cataclysms of recent history, then it is worth looking back at them. (S. Vajda, 1964)

A few years ago at the ASTIN colloquium in Washington Robert Beard presented a paper about the early history of ASTIN. The paper is published in volume 9 of the Astin Bulletin. 25 years ago Beard was in the epicenter of the events or rather he was the epicenter himself. Therefore, it could be regarded as superfluous if so soon after I give my own version of the same events.

In the home of my grandparents I had much fun from an old-fashioned stereoscope. Looking into two glasses at two photographs taken of the same object from slightly different positions, your view gained a new dimension. In other words you could look behind the nearest objects and feel a certain depth in the picture. It is my hope that the reader being familiar with Beard's story and now reading a new version seen from a slightly different personal point of observation, might gain a more detailed view of what happened.

But let us start from the beginning. Several old friends have supported and supplemented my memory, and I am very grateful to them.

\section{1}

The early actuarial activities in the field of life assurance are well known. The investigations of the statistics of human mortality, the mathematical model of the mortality table, and the invention of commutation symbols made possible the mathematical foundation some 200 years ago of scientific life assurance. Each step of the evolution was smoothly communicated to specialists in various countries, and thus the aspect of the actuary as a life assurance mathematician developed during the last century. The Institute of Actuaries was founded in London in 1848, and several other national associations were born during the next generation. An international Permanent Committee was established in 1897 in order to promote actuarial collaboration across borders.

\section{2}

Life assurance was not the only field of mathematical activity in insurance. One phenomenon which from of old attracted the attention was how the fire 
risk varies with the size of the exposed objects. This forms a striking parallel to the variation of mortality risk with age. Tariffs based upon fire risk premium rates increasing with the sums insured were introduced in Denmark in 1857. Even before that-in 1835-a French industrialist, Théodore Joseph Barrois had worked out a mathematical model describing this phenomenon. The same model was independently published by a Russian, Sergius von Sawitsch in 1909. Much later similar results are presented by various other authors, including P. O. Berge and myself. In Italy, d'Addario studied the simultaneous variation of outbreaks of fires and average damage degrees. His results were published in 1940. It is characteristic that in the beginning each author was acting alone. Each knowing little of the works of his predecessors had to start practically from scratch. As a result the total effect of all the efforts was not much greater than that of each individually. The multiplicative effect of collaborating in the research did not come to work.

\section{3}

In the United States quite a different type of risk was studied by a large group of mathematicians and statisticians working in the field of workmen's compensation insurance. According to the law at that time in the States, this insurance line was written exclusively by specialized companies, and for that reason the group in question-organized in 1914 in the Casualty Actuarial Society-had not much contact with actuaries working in life assurance or other fields.

Workmen's Compensation includes policies each covering a substantial number of persons and with many indemnity payments each year. As the risk varies from one policy to the other according to variations of protection, experience rating is useful. So the system of Credibility was developed to decide what weight can be put upon the actual loss experience of the individual risk covered by the policy when assessing next year's premium rate.

\section{4}

About 1920 a group of Italian actuaries had studied the mathematical and statistical bases for evaluating loss reserves in certain non-life fields, and on the agenda of the 1934 congress in Rome we find the theme of assessing premiums and loss reserves in accident and third party liability insurance. Italian speakers proposed formation of an international group of actuaries to promote studies of this subject. Such a group, however, did not materialize.

In 1937 at the Paris congress, several themes on the agenda concerned non-life insurance questions. The subject of reinsurance explicitly covered both life and non-life. One subject considered a possible international statistic of employers' liability insurance and one was devoted to the mathematics of fire and general insurance. In this section also problems from marine insurance were discussed and an international working group was formed to follow up this discussion. Herman Wold and Paul Qvale were among its members and Paul Riebesell was 
appointed Chairman of the group. As the international tension increased during the next few years, this group, however, never really started working. In other circumstances it might have developed into an ASTIN group.

\section{5}

Between the two World Wars two monographs of general insurance theory were published-N. Sergovskij: Einführung in die Theorie der Feuerversicherung, Prague 1931, and Paul Riebesell: Einführung in die Sachversicherungsmathematik, Berlin 1936.

Both authors regard for instance the fire premium rate as a product of an ignition probability and an average loss degree. These two factors are by definition regarded as independent. Reinsurance techniques were described and these as well as general risk theory were based upon the classical individual aspect of risk, and statistical independence of the individual claims was presumed.

These books were quickly outdated as a result of the progress of the statistical science.

\section{6}

In 1909 Filip Lundberg had given the first version of his revolutionary general risk theory. Lundberg's first works are extremely difficult reading. Only many years later the collective risk theory was made more generally accessible by Harald Cramér and his school in the new language of stochastic processes. Cramér has told me that when he was a young actuary of the Swedish Supervision Board, he was asked to study Lundberg's works with the words: Try to explain the meaning of this, it is an attempt to bring some mathematical order into fire insurance.

The collective risk theory does not limit itself to one specific insurance line. It considers the total flow only of premium payments and loss payments of a portfolio, and this portfolio can be a mixture of insurance lines and even of life and non-life. The study of the risk theory is equally important for life and non-life actuaries.

\section{1}

Before the last turn of the century, Danish insurance companies were mostly specialized, each writing one line only: fire, life, or accident. Each company had a great number of part-time agents with maybe the strictly necessary knowledge of one insurance form. During and after the twenties this pattern totally changed. The companies got together into groups or took up new lines of insurance, and each larger unity built up a staff of professional exclusive agents to become insurance advisers covering all the insurance requirements of its clientele. Often a group includes a life company or life was taken up by a non-life company, or vice versa. Similar organizing changes took place in other Scandinavian countries 
and this evolution implied that quite a number of life actuaries became involved in non-life problems.

\section{2}

In 1934 I was working as an actuary in a newly founded life department of an old fire insurance company. By and by I became involved in fundamental questions concerning reinsurance of fire risks. Here in a humble way I tried to take into account a hint of the collective risk theory.

My first opportunity to meet foreign colleagues with similar problems was during the centenary celebrations of the Institute of Actuaries in 1947. In London I paid a visit to Ernest Eldridge, a friend of the company with which I worked, and he introduced me to Robert Beard who had quite recently converted to non-life work. We decided on the spot to keep in touch in order to form a link between the few British and Scandinavian actuaries interested in the mathematics of general insurance. On that day a lifelong companionship and friendship was founded.

\section{3}

At that time my daily work was still within life assurance. But in my spare hours I worked as a statistical adviser to a group of small mutual companies writing mainly fire insurance of rural buildings, an insurance form which according to law was managed by special companies only. In that capacity I had taken over from Gunnar Benktander who had established common risk statistics. Hereby I worked out a mathematical model describing the increase of the fire risk rates with the size of the buildings. Later, in 1957, I published a paper on that model at the congress of New York. By queer accident this model was a special case of the one that Barrois had described some 120 years before. Later, 1959, I was appointed actuary of the Nye Danske af 1864 , being the first to occupy such a position with a Danish non-life company.

\section{1}

During the 1947 London centenary another valuable first contact was made when Franckx, Hillary Seal, Steven Vajda, and Boleslaw Monic met and discussed non-life actuarial problems. Monic, a manager of a reinsurance company was to play a leading role in the coming international organization. It was his firm view that something should be done and he suggested the arrangement of an international competition.

This was the origin of the competition arranged by Monic's company, Algemeene Herverzekering Maatschappij. It took place in 1951-1952, and the jury was composed by Monic, Franckx, Vajda, and Bruno de Finetti, and the theme was non-proportional reinsurance. The top prizes in the competition were awarded to Hans Ammeter and to Jean Sousselier. 
By that initiative a strong continental group of actuaries was formed. This group which was mainly initiated by the efforts of Monic and Franckx, took an active part in the founding process of ASTIN. The abbreviation of Actuarial STudies In Non-life insurance into ASTIN is due to Franckx.

\section{2}

The first post-war international actuarial congress was held in 1951 in Scheveningen. Here Eldridge had arranged a special meeting on excess of loss reinsurance. The meeting became a great success with 4 papers submitted and 59 persons present. Among the speakers were Monic, Beard, and de Jongh. I must confess that although I took part in the congress I did miss that meeting which was the first roll-call of future ASTIN members.

Monic had persuaded de Jongh to take the Chair although de Jongh was not convinced that the congresses were the right forum for excess of loss studies. In 1950 he had tried to found a special excess of loss center with Riebesell, but this was interrupted by Riebesell's death.

\section{3}

In July, 1953 a Scandinavian initiative was taken to found an actuarial study group on non-life matters. H. Hellemann and H. Colding-Jørgensen were working as actuaries in the tariff organizations of general insurance in Norway and Denmark, respectively, and they sent an invitation to their colleagues in similar positions in Sweden and Finland to join them. This resulted in the formation of the Nordic Tariff-organizations' Actuaries (NTA) and already in November, 1953 this group had its first meeting in Ehrendal, Sweden. Present were 14 actuaries working in the tariff organizations of the four countries or the attached companies. The meeting took two full days and the main subject was the scope of the future co-operation on these matters in Scandinavia, but also various specific mathematical models and applications of risk theory were dealt with and a possible extension of the co-operation to other parts of the world.

During the next few years similar meetings were held in Norway, Denmark, and Finland. At the time when a second meeting was to be organized in Sweden, it was decided to convert the NTA meeting into the ASTIN colloquium of Rättvik and so the specific NTA activities ended.

The NTA had a letter club where stencilled papers on recent research were circulated. Through me a close contact to ASTIN was established, and at one NTA meeting a new draft of the ASTIN rules was worked out which became the lay-out for the actual ASTIN rules.

During the NTA period the interest for non-life problems was growing in Scandinavian actuarial associations. Several papers on non-life problems were read at the meetings. In Denmark where I was President of the Society from 1953 to 1959 we had normally one non-life subject each year. In Sweden the Board of the Society was supplemented with a member having special insight 
in general insurance. In 1954 the first candidate for that seat was Ingvar Sternberg.

\section{1}

The Council of the Permanent Committee for International Actuarial Congresses-now the International Actuarial Association-held its annual meeting in Brussels on September 26th, 1953. The President was A. Theate and the General Secretary, Charles Boels, by tradition chosen among the members of the Belgian delegation. Present were 21 members from 8 countries. Among those present for the first time were Edouard Franckx and myself. For us this should be the beginning of a close collaboration and of a very long service on this Committee.

Towards the end of the meeting Prof. Engelfriet of Holland informed the Council that he had heard of the recent establishment of a new international association of actuaries outside the Permanent Committee, and he asked if any member could give information about this group and its aims.

Franckx replied that some actuaries would like to form an international group interested in the application of actuarial techniques to problems of non-life branches. The group was not to be considered as dissident from the Permanent Committee but quite on the contrary hoped to have the support and the patronage of the Committee.

The President thanked Franckx and expressed the interest of the meeting. $\mathrm{He}$ promised all possible help on the part of the Committee towards the achievement of the object which the promoters of this new association had in view.

\section{2}

In a circular letter of November, 1953 the group presented itself like this:

"A number of persons interested in insurance have noticed that whereas the study of life assurance, thanks to the contributions of actuaries of all countries, has attained a remarkable degree of scientific development, the theory of non-life branches has hardly been touched.

Judging by the response from various countries, it seems that it would be worth while to make a common effort in order to try to fill this gap in the scientific field.

For this purpose the undersigned have formed a Preparatory Committee and one of them, Monsieur Franckx, has had the opportunity to submit a summary of its aims to the Council of the Comite Permanent des Congrès Internationaux d'Actuaires at a meeting held on 26th September, last. Through its President the Comite Permanent promised to lend all possible support to the project.

If, as we hope, you share our interests in the matter, the Preparatory Committee would be pleased if you will join them by becoming a founder member at the proposed Association for Actuarial Studies in Non-life Insurance (ASTIN). 
If you think that our efforts deserve to be more widely known, we shall be grateful if you will mention them to other colleagues and let us have their names and qualifications.

We attach suggested Articles of Association, but this is only a first draft and we shall welcome any criticism or alternative proposals.

It is hoped that it will be possible, on the occasion of the forthcoming International Congress in Madrid, to arrange a private meeting of all founder members in order to proceed with the formation of the Association."

\section{3}

This letter was signed by Ammeter, de Finetti, Franckx, de Jongh, Monic, Sousselier, and Vajda. With the letter followed the draft rules of the association. The content of these rules was in short that the aim was co-operation and exchange of scientific information between persons interested in the actuarial aspects of insurance, mainly connected with branches other than life. The association should publish papers on topics related to its aims and a bulletin containing notes of general interest to members. The association should hold discussion meetings as and when convenient and conferences not less frequently than every three years.

The association should establish contact both locally and internationally with other bodies of similar interest. Nothing specifically was mentioned about the contact with the Permanent Committee.

The wording of these rules caused some doubt among the members of the Council. Several were in doubt whether this association merited the support of the Permanent Committee. In a letter to Franckx the Bureau stated that the question of support to ASTIN would be restudied at the next committee meeting in Madrid. Until then, the ASTIN Preparatory Committee should not talk too much about this support.

\section{4}

On June 2nd, 1954 the Council of the Permanent Committee met in Madrid before the opening of the 14th international congress. The agenda had a special item: Possibility of forming a new international association of actuaries (ASTIN).

The President, Théate recalled the circumstances in which this question came before the Permanent Committee at the last meeting, and read the letter which he had sent to ASTIN in order to avoid any misinterpretation of the minutes of the meeting.

Several members drew attention to the fact that the actuarial associations of the different countries had often taken an interest in actuarial matters other than those proper to the life branch, various questions relating to non-life business having in fact been dealt with at previous congresses. As both the Permanent Committee and the national actuarial associations had shown their interest in actuarial development in all fields, the technical study of non-life matters could 
easily be conducted within the framework of the existing associations without it being necessary to form an independent international organization.

Sir George Maddex suggested the formation-within the framework of the Permanent Committee - of sub-committees for the technical study of non-life problems.

Albert Linton said that in the United States the Casualty Actuarial Society was dealing with questions other than life, but up to now that Society had not developed to any great extent. I stated that in Scandinavia a number of members of the national actuarial societies had founded a group for studies in non-life actuarial problems and that this group was eager to get in contact with colleagues in other countries.

Franckx reaffirmed that the creation of ASTIN was not in conflict with the Permanent Committee. The statutes of ASTIN could be altered to avoid being interpreted as in conflict with those of the Permanent Committee. He did not refuse to contemplate the setting up of a special non-life sub-committee under the Permanent Committee.

It was pointed out that the 14th congress would discuss questions which did in effect come into the scope of ASTIN.

Concluding, it was decided that the Permanent Committee should reestablish contact with the ASTIN officials and at Sir George Maddex' suggestion, Théate and Boels were asked to look into the matter again with Franckx.

\section{5}

The ASTIN meeting during the congress developed as planned and among the speakers were Bertil Almer, Ammeter, and Sternberg. A preliminary ASTIN committee was elected: Beard, Franckx, Monic, and myself.

The audience of the meeting, however, was very small. It had proved impossible to announce the meeting through the official channels of the congress, so only a handful of directly addressed people had some kind of clandestine gathering. But there was Spring in the air when the founding fathers closed this first ASTIN meeting.

\section{6}

The following meeting of the Permanent Committee was held in Brussels on September 24th, 1955. Here, Professor Marchand submitted a plan for modifying the regulations of the Permanent Committee to allow for the co-operation of this body with ASTIN. In short his plan was that sections formed by a number of members for studies of special problems might be recognized. Each such section should be represented on the Council of the Permanent Committee by at least one member.

In general the proposal of Marchand was supported in the following discussion. It was stated that all members of the Permanent Committee might participate in the work of such sections. It was decided that the Permanent Committee 
should be represented on the Board of a section by at least one member, and not vice versa.

The question was raised, if persons who were not actuaries could become members of these sections. Here, Franckx stated that indeed it would be so. These persons, nevertheless, would not be ordinary members of the section, but only invited to participate in the work of the section on account of their special knowledge.

It was approved that the Bureau should prepare a new wording of the regulations to embody the various considerations put forward, to be submitted to the next general meeting in September, 1956.

\section{7}

During the following year a new proposal was worked out in complete agreement with the founder members of ASTIN, and after approval by the national associations the modifications were submitted to the Council. These modifications allowed for sections formed by a number of members for studies of special problems. Each section should have its own regulations, previously approved by the Council and should elect its committee, except for the member appointed by the Permanent Committee.

The wording was accepted by the Council to be put before the coming 15th congress in New York and Toronto. I could confirm that any member of the Permanent Committee had the right to participate in the work of the section and that the members of the ASTIN section, in my view, should be full members of the Permanent Committee.

\section{8}

Next time the Council held its meeting in New York before the opening of the congress. The draft rules for the ASTIN section were approved by the Council and Sir George Maddex was nominated the first delegate of the Permanent Committee to the ASTIN committee.

Before the next annual meeting Charles Boels, the General Secretary of the Permanent Committee suddenly died. As his successor was appointed Edouard Franckx. In September, 1958 at the Council meeting in Brussels, I gave a report on the first activities of ASTIN. I said that it had not been easy to constitute an effectively working international group, but it was my conviction that those involved were on the right way. I promised that in future more should be heard about ASTIN activities.

The recognition process as we have seen was long and tedious. What was wrong or what went wrong? Maybe the first attempt was regarded a little 
suspicious because Monic represented a young reinsurance company with new ideas of reinsurance treaties.

An original strong support came from Scandinavia and Marchand's initiative was important.

The opposition at a certain point was predominant in Britain whère actuaries were interested in life only and general insurance was dealt with by the Chartered Institute. There was a fear that outsiders should flood the actuarial profession and therefore the question of admission of non-actuaries to ASTIN could be a crucial point. It was only the whole-hearted efforts of Beard, a generally estimated former life actuary and the support of George Maddex who as the Government's Actuary had an immensely recognized position that made possible a British opening to ASTIN.

In the United States up to the congress of 1957 there was an approach between life and non-life actuaries. Francis Perryman who has held in great esteem by both sides played a decisive role.

In France, a small number of actuaries were very much occupied with bonus in motor insurance and at an early stage, Marcel Henry issued an invitation to Franckx to a meeting which should be the first ASTIN colloquium in la Baule.

\title{
7
}

Finally the great day had come, the day for which we had worked hard and looked forward to through ten long years. The formation of ASTIN was formally accepted, and one of the themes of the congress papers had been chosen by the Preparatory Committee. A cocktail party was given in our honour by the Casualty Actuarial Society, and our activities during the congress were officially recognized and properly announced. Everything went smoothly.

At 2.30 p.m. on October 16 th 1957 the inaugural meeting took place at the Hotel Commodore. The President of the Casualty Actuarial Society, Doc Masterson presided and 46 persons were attending. You can read about all that happened in volume 1 of the Astin Bulletin.

Franckx gave a report on behalf of the Preparatory Committee and papers on former non-life actuarial activities were presented by Lars Wilhelmsen, Longley-Cook, Ammeter, Depoid, and de Finetti.

The first ASTIN committee as proposed by Doc Masterson was unanimously accepted and also the draft of the rules. Besides George Maddex, who was appointed by the Permanent Committee, the committee was composed of the four members of the Preparatory Committee, and in addition Francis Perryman and Carl Philipson. At the first meeting of the new committee with George Maddex in the Chair these appointments were made

\author{
Chairman Johansen \\ Vice-Chairman Perryman \\ Editor Franckx \\ Secretary Beard \\ Treasurer Monic
}




\section{1}

A question with high priority was the organizing of the Bulletin. Besides the editor an editorial panel was formed consisting of Ammeter, de Finetti, Depoid, Engelfriet, Longley-Cook, and C.-O. Segerdahl.

The heavy commitments falling on Franckx in connection with the 16th congress to be held in Brussels made it necessary that he should be relieved of his editorial work and so Beard took over provisionally besides his secretarial job. He had a tremendous load of work and did it well.

\section{2}

It was decided that the office of Chairman should rotate rather frequently so that many nations successively can have that honour. Therefore, a long series of actuaries from many countries have already served their two years' term and given their devotion and inspiration to ASTIN.

From an early stage the treasury has been handled from Brussels, this being practical as the fees are paid together with those of the IAA. The secretarial work has always been done in London. They both speak and write English so well, these Britons.

During the first 25 years quite a number of ASTIN members have served on its committee. We owe them thanks but they will not be named here. Some of them have passed away. We miss them and mourn them.

\section{3}

The 15th ASTIN colloquium is organized in Loen, Norway, and the 16th in 1982 in Brussels will coincide with ASTIN's 25 years.

Much work has been done in order to prepare and organize these meetings. I can speak about it because I was involved with the colloquium of Randers. Each has had its specific melody and each has introduced new ideas and added to the success of ASTIN. Again, I can speak about it being the only one who has participated in all these colloquia.

From the beginning we tried to create some efficient tools for international collaboration. A few days of intensive work, often in a place remote from the temptations of the big cities and without too much social activity, can bring your research a long step forward. With a much smaller audience than the big congresses it is possible to create an intimate atmosphere of discussion and the dialogue can sometimes become a wonderful mathematical ping-pong.

For practical reasons the languages have always been restricted to English and French only. Participants in the colloquia must have knowledge of both languages in order to get the full result of the dialogue. On the other hand, any speaker should do his utmost to speak slowly and clearly. Whichever language he uses, it will be a foreign language to the majority of the audience. With this linguistic restriction we can avoid too much costly-and not always effectivetranslation, which can be a hindrance to the spontaneity of the exchange of views. 
Strange things have happened which can enlighten the memoirs of an old ASTIN fan, like the story of a certain Lady Evelyn who never turned up. I had suggested an informal meeting in Brussels with Beard and Maddex and received a cryptic answer by telegram:

\section{MEETING EVELYN FRIDAY SATISFACTORY SIR GEORGE AND MYSELF STOP BEARD.}

The mysterious Lady was an error of interpretation, Evelyn instead of evening.

In some places a Secretary is even more equal than others. During the colloquium of Sopot, Poland the imperial suite of the fine, old hotel was offered to our Secretary, Peter Green, while the Chairman had to be content with a more modest room like those of the other participants.

At the same colloquium a committee was formed to thoroughly formulate the themes of the coming meeting in Randers to attract the interest of Eastern European actuaries. In that committee were participants from Finland, Poland, and Czechoslovakia, and in a moment of inspiration I asked them to finish the text, polish the words, and check the result.

At intervals ASTIN's eternal crisis has been discussed. As probably in all similar associations there are some members who want to know a little about everything and others who know practically everything about very little, and this little is often regarded as of still less practical use by the first.

By this feud lowbrows and highbrows may still influence each other. Some find this fighting awful. I do not-I find it reciprocally much inspiring. ASTIN must have room for both theorists and practicians in order to thrive and until now we have had many fine representatives of both camps. ASTIN must always keep the nose in the sky and the feet planted in solid soil.

11

During the first 25 years ASTIN has grown from a handful of members to well over 1000. 12 volumes of the Bulletin contain most of the papers presented at the colloquia, the subject varying from specific mathematical models or statistics from various non-life insurance fields to fundamental basic research.

What will happen in the future? The general technological, economic, and social development will certainly continue. This will inevitably imply that new risks will arise and grow, which will call for new kinds of insurance coverage. Enormous risk accumulation will call for more insurance coverage and new thoughts in reinsurance.

In this process technical specialists will be needed with the background of a qualified actuarial education. This will be a challenge to ASTIN and to its members. 